\title{
ANALISIS PENGARUH UNDERSTANDING CUSTOMER EXPECTATION (UCE) DAN BUILDING SERVICE PARTNERSHIP (BSP) TERHADAP LOYALITAS NASABAH PADA PT. BANK NEGARA INDONESIA (PERSERO) TBK KANTOR CABANG PEMBANTU LAMONGAN
}

\author{
*( Henny Mahmudah \\ Prodi Manajemen, Fakultas Ekonomi, Universitas Islam Lamongan \\ $\mathrm{Jl}$. Veteran No.53A Lamongan \\ Telp. ( 0322 ) 324706, Faks. ( 0322 ) 324706 \\ Email:jpim.unisla@gmail.com
}

\begin{abstract}
ABSTRAKSI
Penelitian ini memberikan gambaran pengaruh Understanding Customer Expectation (UCE) dan Building Service Partnership (BSP). Strategi tersebut cara mensukseskan program perusahaan yang bertujuan memberikan pelayanan baik dan memuaskan guna mengetahui loyalitas nasabah. Penelitian ini menganilisis pengaruh variabel Understanding Customer Expectation $\left(X_{1}\right)$ dan Building Service Partnership $\left(X_{2}\right)$ terhadap loyalitas nasabah (Y). Dengan hipotesis : variabel Understanding Customer Expectation $\left(X_{1}\right)$ dan Building Service Partnership $\left(X_{2}\right)$ berpengaruh simultan dan parsial terhadap loyalitas nasabah $(Y)$ serta diduga Building Service Partnership $\left(X_{2}\right)$ berpengaruh dominan terhadap loyalitas nasabah (Y). Menggunakan metode Analisi Regresi Linier Berganda, Uji $t$, Uji F. Regresi linier berganda diperoleh persamaan $Y=$ 2,403+0,190 $X_{1}+0,277 X_{2}$ berarti apabila terjadi kenaikan satu Understanding Customer Expectatio maka akan menaikkan loyalitas nasabah sebesar 0,190 dan apabila Building Service Partnership mengalami kenaikan satu Building Service Partnership maka akan menaikkan loyalitas nasabah sebesar 0,277. Uji $t$ untuk Understanding Customer Expectatio $t_{\text {hitung }} 2,605>t_{\text {tabel }}$ 1,9883 berarti ada pengaruh yang signifikan terhadap loyalitas nasabah, sedangkan Building Service Partnership adalah thitung 4,283 $>t_{\text {tabel }}$ 1,9883 berarti ada pengaruh yang signifikan terhadap loyalitas nasabah. Uji $F$ dilihat bahwa Understanding Customer Expectation (UCE) dan Building Service Partnership (BSP) berpengaruh positif dan signifikan terhadap loyalitas nasabah dengani nilai $F_{\text {hitung }}>F_{\text {tabel }}$ sebesar 97,653>2,465. Disimpulkan Understanding Customer Expectation (UCE) dan Building Service Partnership (BSP) signifikan terhadap loyalitas nasabah perusahaan.
\end{abstract}

Kata kunci : Understanding Customer Expectation, Building Service Partnership dan Loyalitas 


\section{PENDAHULUAN}

Perusahaan perbankan dan jasa keuangan, saat ini dihadapkan pada persaingan yang sangat tajam, kompleks dan perubahan lingkungan bisnis yang cepat. Persaingan menjadi semakin ketat setelah bank asing turut memperebutkan nasabah pada pasar yang sama. Lembaga keuangan non bank yang beroperasi secara lebih khusus juga semakin banyak. Situasi ini menggambarkan betapa ketatnya persaingan untuk meraih pangsa pasar yang lebih luas. Kesuksesan dalam persaingan dunia perbankan akan terpenuhi apabila dapatmenciptakan dan mempertahankan nasabah karena nasabah yang loyal merupakan asset terbesar yang harus dijaga perusahaan. Mempertahankan semua nasabah yang ada umumnya akan lebih menguntungkan dibandingkan dengan pergantian nasabah.

Loyalitas mutlak diperlukan perusahaan perbankan untuk tetap survive dan mampu bersaing dengan bank atau jasa keuagan lainnya sehingga terbentuk persepsi kualitas yang kuat di benak nasabah. Loyalitas nasabah terhadap suatu bank dapat disebabkan oleh beberapa factor, seperti citra baik yan dimiliki bank tersebut, kualitas pelayanan yang diberikan dan kepuasan terhadap bank. Untuk membangun, memenangkan dan menjaga loyalitas pasar bukanlah perkara yan datang tanpa disadari strategi cermat yang dibuat oleh perusahaan. Perusahaan harus memahami apa yang dibutuhkan dan diinginkan oleh nasabah dimasa sekarang atau dimasa yang akan datang. Dalam hal ini nasabah diamsusikan telah memiliki pengetahuan dan informasi yang sempurna berkaita dengan kputusan konsmsinya. Melalui informasi yang dimiliki, nasabah akan membandingkan antara produk satu dengan produk lainnya dan nasabah harus tetap dijaga dan dipertahankan agar tidak bepaling ke perusahaan pesaing.

Understanding

Customer

Expectation (UCE) dan Building Service Partnership (BSP) dipandang mampu untuk mempertahankan loyalitas nasabah yang sangat relevan untuk diterapkan dalam strategi pemasaran jasa. Kedua strategi tersebut mejadi senjata perusahaan unuk terus dapat bertahan di pasar dengan memenangkan loyalitas dari pelanggan yang telah mereka miliki. Loyalitas nasabah harus dibangun dengan usaha keras dalam bentuk personaliasi dimana nasabah menjadi inti dari aktivitas pemasaran. Nasabah yang memiliki maksud untuk menggunakan kembali dan merekomendasikan produk dan jasa kepada orang lain kemungkinan besar sebagai pelanggan yang loyal. Sehingga dalam perusahaan perbankan usaha-usaha Understanding

Customer Expectatio(UCE) dan Building Service Partnership (BSP) dilakukan untuk menambah kedekatan dengan nasabah dan tujuan utama dari usaha tersebut adalah untuk menjaga agar nasabah tetap loyal kepada perusahaan.

Understanding

Customer

Expectatio(UCE) yang ditujukan dengan menjual produk dengan harga yang dapat dijangkau bagi nasabah, menyediakan fasilitas yang sesuai dengan apa yang diharapkan oleh nasabah, menanggapi opini-opini dari nasabah, merespon complain dari nasabah. Building Service Partnership (BSP) adalah mengajak para pelanggan ikut serta dalam program-program yang diadakan oleh pihak perusahaan, 
menganggap nasabah sebagai partner, memberikan layanan tambahan berup pelayanan yang cepa kepada para nasabah, selalu menjaga hubungan baik dan kerjasama yan erat dengan nasabah. Usaha-usaha Understanding Customer Expectatio(UCE) dan Building Service Partnership (BSP) juga mencakup tuntutan manajemen mutu (Total Quality Management) yang dituntut agar selalu berinovasi dalam perbaikan mutu produk.

Berdasarkan tersebut di atas maka penulis bermaksud mengadakan penelitian dengan judul " ANALISIS PENGARUH UNDERSTANDING CUSTOMER EXPECTATIO (UCE) DAN BUILDING SERVICE PARTNERSHIP (BSP) TERHADAP LOYALITAS NASABAH PADA PT. BANK NEGARA INDONESIA (PERSERO) TBK KANTOR CABANG PEMBANTU LAMONGAN".

Berdasarkan latar belakang diatas, maka dapat dirumuskan masalah sebagai berikut : Apakah keinginan pelanggan (Understanding Customer Expectatio) (UCE) dan membangun pelayanan kemitraan dengan pelanggan (Building Service Partnership) (BSP) secara parsial berpengaruh signifkan terhadap loyalitas nasabah pada PT. Bank Negara Indonesia (persero) tbk Kantor Cabang Pembantu Lamongan, Apakah keinginan pelanggan (Understanding Customer Expectatio) (UCE) dan membangun pelayanan kemitraan dengan pelanggan (Building Service Partnership) (BSP) secara simultan berpengaruh signifikan terhadap loyalitas nasabah pada PT. Bank Negara Indonesia (persero) tbk Kantor Cabang Pembantu Lamongan, dan Manakah diantara keinginan pelanggan (Understanding Customer
Expectatio) (UCE) dan membangun pelayanan kemitraan dengan pelanggan (Building Service Partnership) (BSP) yang berpengaruh dominan terhadap loyalitas nasabah pada PT. Bank Negara Indonesia (persero) tbk Kantor Cabang Pembantu Lamongan.

Tujuan dari peneilitian ini adalah untuk mengetahui keinginan pelanggan (Understanding Customer Expectatio) (UCE) dan membangun pelayanan kemitraan dengan pelanggan (Building Service Partnership) (BSP) secara parsial berpengaruh signifkan terhadap loyalitas nasabah pada PT. Bank Negara Indonesia (persero) tbk Kantor Cabang Pembantu Lamongan, untuk mengetahui keinginan pelanggan (Understanding Customer Expectatio) (UCE) dan membangun pelayanan kemitraan dengan pelanggan (Building Service Partnership) (BSP) secara simultan berpengaruh signifikan terhadap loyalitas nasabah pada PT. Bank Negara Indonesia (persero) tbk Kantor Cabang Pembantu Lamongan dan untuk mengetahui diantara keinginan pelanggan (Understanding Customer Expectatio) (UCE) dan dan membangun pelayanan kemitraan dengan pelanggan (Building Service Partnership) (BSP) yang berpengaruh dominan terhadap loyalitas nasabah pada PT. Bank Negara Indonesia (persero) tbk Kantor Cabang Pembantu Lamongan.

\section{LANDASAN TEORI}

Penelitian terdahulu yang dilakukan oleh Lilik Afi Wibowo, 2007 Universitas Muhammadiyyah Yogyakarta dengan judul "Implementasi Relationship Marketing Terhadap Customer Lolality (Studi Kasus Pada Bank Rakyat Indonesia Cabang Cik Di Tiro di Yogyakarta)". 
Dari uji $t$ menjukkan variabel Understanding Customer Expectatio $\left(\mathrm{X}_{1}\right)$ memiliki koefisien beta positif sebesar 0,211 dengan signifikan 0,007 $<\alpha(0,05)$, variabel Building Service Partnership $\left(\mathrm{X}_{2}\right)$ memiliki koefisien beta positif sebesar 0,409 dengan signifikan $0,000<\alpha(0,05)$, variabel Total Quality Management $\left(\mathrm{X}_{3}\right)$ memiliki koefisien beta positif sebesar 0,179 dengan signifikan $0,024<\alpha$ (0,05), variabel Empowering Employess $\left(\mathrm{X}_{4}\right)$ memiliki koefisien beta positif sebesar 0,252 dengan signifikan $0,000<\alpha(0,05)$ menyimpulkan bahwa variabel Building Service Partnership mempunyai pengaruh yang dominan terhadap Customer Loyalty (Y) pada Bank Rakyat Indonesia Cabang Cik Di Tiro di Yogyakarta.

Kemudian penelitian terdahulu yang dilakukan oleh Maulana Sayuti, 2011 Universitas Brawijaya Hasanuddin Makassar dengan judul "Pengaruh Implementasi Realitionship Marketing Terhadap Customer Loyalty pada PT. Bank Negara Indonesia (Persero), Tbk. Kantor Cabang Utama Mattoangin Makassar". Dari uji t menjukkan variabel Understanding Customer Expectatio $\left(\mathrm{X}_{1}\right)$ memiliki koefisien beta positif sebesar 0,183 dengan signifikan $0,012<\alpha(0,05)$, variabel Building Service Partnership $\left(\mathrm{X}_{2}\right)$ memiliki koefisien beta positif sebesar 0,446 dengan signifikan 0,000 $<\alpha(0,05)$ menyimpulkan bahwa variabel Building Service Partnership mempunyai pengaruh yang dominan terhadap Customer Loyalty (Y) pada PT. Bank Negara Indonesia (Persero), Tbk. Kantor Cabang Utama Mattoangin Makassar. Persamaan pada penelitian ini dengan kedua penelitian sebelumnya terletak pada variabel terikatnya yaitu pada loyalitas nasabah
(Y). Sedangkan perbedaan pada penelitian ini dengan kedua penelitian sebelumnya terletak pada variabel bebas $(\mathrm{X})$ dan tempat/obyek penelitian.

Menurut Chan S (2003) mengenai Understanding Customer Expectation (UCE) yakni selain sisi teknologi, perusahaan dan pemasarannya juga berlomba untuk memodifikasi strategi pemasarannya. Mereka semakin mengerti bahwa pelanggan adalah nyawa atau kehidupan bagi sebuah perusahaan. Pelanggan, terutama pelanggan yang loyal, harus tetap dijaga dan dimanjakan agar tidak berpaling ke perusahaan lain. Sebuah perusahaan harus mempunyai strategi untuk dapat selalu mempertahankan pelanggannya, disamping itu perusahaan harus bisa mengidentifikasikan apa yang diharapkan atau diinginkan pelanggan. Sehingga semua produk yang ditawarkan, proses penawaran sampai pada cara bertransaksi disesusaikan dengan keinginan setiap indovidu pelanggan tersebut.

Menurut Powers (1998) Kegiatan ini melibatkan kemampuan perusahaan untuk melakukan identifikasi apa yang diinginkan oleh pelanggan dan memasarkan barang/jasa diatas tingkat yang mereka harapkan. Meskipun konsep tersebut sederhana banyak perusahaan mengalami kesulitan dalam melakukan identifikasi harapanharapan pelanggannya karena mengalami kesenjangan antara apa yang diinginkan pelanggan dengan apa yang diberikan oleh perusahaan (sudut pandang pelanggan) dan adanya kesenjangan antara apa yang dipercaya oleh perusahaan tentang keinginan pelanggan dengan apa yang sesungguhnya diinginkan oleh pelanggan (sudut pandang perusahaan). 
Dengan memahami harapan pelanggan tentang kualitas pelayanan akan memberikan manajemen da pegawai perusahaan untuk membuat usaha yang terkonsentrasi pada kepuasan pelanggan.

Building Service Partnership $(B S P)$ yakni pengalaman kemitraan ada ketika suatu perusahaan bekerja sama secara erat dengan pelanggan dan menambahkan pelayanan yang diinginkan oleh konsumen atau suatu produk perusahaan. Menurut Evan dan Laskin dalam Wibowo S (2006) beberapa pertimbangan dalam membangun pelayanan kemitraan adalah kedua pihak yaitu penjual dan pemebli memiliki fokus yang sama mengenai kebutuhan spesifik yang ingin dicapai masing-masing harus merasa dalam posisi "win-win", kedua pihak merupakan kolaboratif yang harus bekerjasama mencapai tujuan bersama; kedua pihak harus melakukan antisipasi adanya masalah; mitra yang baik memasukkan rencana aksi yang akan dilakukan dalam menangani masalah; kedua pihak bekerja dan merencanakan bagaimana menangani perubahan harga, melakukan ekspansi dan melakukan konsilidasi; kedua pihak bekerja bedasarkan kejujuran dan keterbukaan dan harus memiliki komunikasi yang teratur.

Memiliki nasabah yang loyal adalah salah satu tujuan akhir dari perusahaan karena loyalitas nasabah dapat menjamin kelanggengan hidup perusahaan dalam jangka panjang. Menurut Oliver dalam Hurriyati (2005: 129) Loyalitas pelanggan adalah komitmen pelanggan bertahan secara mendalam untuk berlangganan kembali atau melakukan pembelian ulang produk atau jasa terpilih secara konsisten dimasa yang akan datang, meskipun pengaruh situasi dan usahausaha pemasaran mempunyai potensi untuk menyebabkan perubahan perilaku. Pelanggan yang loyal memiliki karakteristik Griffin, 2002 : 31) : melakukan pembelian secara teratur, membeli diluar lini produk/jasa, merekomendasikan produk lain, menunjukkan kekebalan dari daya tarik produk sejenis dari persaingan. Serta dapat memberikan keuntungan bagi perusahaan yaitu dapat mengurangi biaya pemasaran, mengurangi biaya transaksi, mengurangi biaya turn over konsumen, meningkatkan penjualan silang yang akan memperbesar pangsa pasar perusahaan, mendorong word of mouth yang lebih positif dan mengurangi biaya kegagalan. Kesetiaan pelanggan merupakan interaksi antara sikap dan perilaku yang tidak bersifat satu dimensional. Melalui interaksi antara sikap dan perilaku, maka terdapat tiga segmen pelanggan/nasabah yaitu true loyalty, latent loyalty dan spurious loyalty.

Scott Robinette dalam Hurriyati (2005 : 125 ) mengungkapkan bahwa terdapat pengaruh antara nilai, loyalitas dan profit. Semakin tinggi nilai yang dirasakan semakin tinggi pula loyalitas dan profit yang diperoleh pelanggan. Untuk meningkatkan loyalitas, perusahaan harus meningkatkan kepuasan dalam jangka panjang. Dan untuk meningkatkan kepuasan, perusahaan harus menambahkan nilai yang dapat membuat mereka mendapatkan apa yang mereka bayar atau lebih dari yang mereka harapkan, sehingga mereka dapat bertahan dan mengarah pada pembelian ulang, perekomendasian dan proporsi pembelanjaan yang meningkat.

Menurut Stanley A. Brown (2000 : 58), loyalitas pelanggan/nasabah 
memiliki tahapan sesuai dengan customer lifetime value. Tahapan tersebut adalah the courtship, the realitionship dan the marriage. Tahapa loyalitas tersebut sebanding dengan cutomer lifetime value. Menurut Syafrudin Chan (2003 : 89) lifetime value adalah profit yang dihasilkan masing-masing nasabah dalam waktu tertentu. Semakin lama seseorang menjadi nasabah, maka semakin besar value pelanggan tersebut bagi perusahaan. Oleh karena itu kebijakan pemasaran yang diterapkan harus dapat mempertahankan nasabah dalam jangka waktu panjang. Strategi yang dilakukan perusahaan kaitannya dengan tahapan loyalitas menurut Stanley (2000 : 69) dibagi menjadi tiga tahap yaitu tahap pertama customer acquisition, tahap kedua customer retention dan tahap ketiga strategic customer care. Menurut Jill Griffin (2005 : 22) ada empat jenis loyalitas yang berbeda muncul bila keterikatan rendah dan tinggi diklasifikasi-silang dengan pola pembelian ulang yang rendah dan tinggi yaitu tanpa loyalitas, loyalitas yang lemah, loyalitas tersembunyi dan loyalitas premium.

Dengan demikian hubungan Understanding Customer Expectation (UCE) dan Building Service Partnership (BSP) terhadap loyalitas nasabah adalah kemampuan perusahaan untuk melakukan identifikasi apa yang diinginkan oleh pelanggan/nasabah dan memasarkan barang/jasa diatas tingkat yang mereka harapkan guna membangun pelayanan kemitraan sehingga munculah kesetiaan (loyalitas) konsumen terhadap suatu produk/jasa.

\section{METODE PENELITIAN}

Waktu peneilitian dimulai bulan Januari 2014 sampai dengan Juni 2014. Penelitian ini dilakukan pada PT. Bank Negara Indonesia (Persero) Tbk Kantor Cabang Pembantu Lamongan. Jalan Jaksa Agung Suprapto Lamongan. Dalam penelitian ini peneliti menggunakan jenis penelitian kuantitatif. Penelitian kuantitatif yaitu penelitian yang dilakukan pada taraf atau kajian dan analisis semata-mata ingin mengungkapkan suatu gejala atau pertanda dan keadaan sbegaimana meztinya berdasarkan pada perhitungan yang objektif untuk memecahkan masalah yang sifatnya dapat diukur. Bedasarkan pengertian tersebut maka dalam penelitian ini sampel diambil dari nasabah PT. Bank Negara Indonesia (persero) tbk Kantor Cabang Pembantu Lamongan yang kebetulan ada pada saat penelitian sampai sejumlah sampel yang ditentukan.

Populasi menurut DR. Sugiyono (2012 : 61) adalah wilayah generalisasi yang terdiri atas obyek/subyek yang mempunyai kuantitas dan karakteristik tertentu yang ditetapkan oleh peneliti untuk dipelajari dan kemudian ditarik kesimpulannya. Dalam penelitian ini yang menjadi populasi adalah nasabah PT. Bank Negara Indonesia (persero) tbk Kantor Cabang Pembantu Lamongan.

Sampel menurut DR. Sugiyono (2012 : 62) adalah bagian dari jumlah dan karakteristik yang dimiliki oleh populasi tersebut. Karena sampel adalah merupakan bagian dari populasi maka sampel harus mempunyai karakteristik-karakteristik seperti yang dimiliki oleh populasi. Sampel dalam penelitian ini adalah sebagian atau wakil dari populasi di PT. Bank Negara Indonesia (persero) tbk Kantor Cabang Pembantu Lamongan. 
Menurut Prof. Dr. Sugiyono (2013 : 118) teknik sampling merupakan teknik pengambilan sampel. Karena karakteristik dari sampel yang sangat beragam, maka pengambilan sampel tidak bisa sembarangan dan hanya menghitung dari prosentase populasi. Dalam penelitian ini menggunakan sampling insidental yaitu teknik penentuan sampel berdasarkan kebetulan, yaitu siapa saja yng secara kebetulan/insidental bertemu dengan peneliti dapat digunakan sebagai sampel, bila dipandang orang yang kebetulan ditemui itu cocok sebagai sumber data. (Prof. Dr. Sugiyono, 2012 :67).

Prof. Dr. Arikunto (2010 : 22) data primer adalah data dalam bentuk verbal atau kata-kata yang diucapkan secara lisan, gerak-gerik atau perilaku yang dilakukan oleh subjek yang di percaya, dalam hal ini adalah subjek penelitian (informan) yang berkenaan dengan variabel yang diteliti. Teknik yang dapat digunakan peneliti untuk mengumpulkan data primer antara lain observasi, wawancara, diskusi terfokus (Focus Group Discussion -FGD) dan penyebaran angket. Dalam penelitian ini data primer adalah data yang dikumpulan dan diolah sendiri oleh peneliti langsung dari responden berupa data opini dan kuisioner yang disebarkan. Kuisioner berisi daftar pertanyaan yang terstruktur dan materinya berhubungan dengan relationship marketing dan pengaruhnya terhadap loyalitas nasabah.

Prof. Dr. Arikunto (2010 : 22) data sekunder adalah data yang diperoleh dari dokumen-dokumen grafis (tabel, catatan, notulen rapat, SMS, dan lainlain), foto-foto, film, rekaman video, benda-benda dan lain-lain yang dapat memperkaya data primer. Dalam penelitian ini data sekunder merupakan data yang diperoleh tidak lanngsung, yaitu data tersebut diperoleh dan diolah dari sumber PT. Bank Negara Indonesia (persero) tbk Kantor Cabang Pembantu Lamongan.

Instrument-instrumen yang dipergunakan antara lain studi kepustakaan adalah cara untuk memperoleh data yang sifatnya data sekunder yaitu dengan mempelajari literature-literatur yang ada di perpustakaan serta dengan cara browsing internet untuk mencai artikel dan jurnal atau data-data. Studi lapangan yaitu penelitian yang dilakukan dengan cara langsung ke perusahaan untuk mendapatkan data primer melalui penyebaran kuisioner yang dibagikan kepada nasabah PT. Bank Negara Indonesia (persero) tbk Kantor Cabang Pembantu Lamongan. Responden diminta menanggapi pertanyaan yang diberikan dengan cara menjawab daftar pertanyaan tentang seberapa besar penilaian mereka atas pengaruh Understanding Customer Expectatio(UCE) dan Building Service Partnership (BSP) terhadap loyalitas nasabah. Jenis kuisioner yang akan digunakan adalah kuesioner tertutup dimana responden diminta untuk menjawab pertanyaan dengan memilih jawaban yang telah disediakan.

Untuk memperoleh data yang relevan terhadap penelitian ini maka metode yang digunakan oleh peneliti meliputi interview atau wawancara yakni dengan menggunakan pertanyaan lisan kepada subyek penelitian berdasarkan daftar pertanyaan yang dibuat, sederhananya mengadakan Tanya jawab langsung kepada nasabah. Kuisioner merupakan teknik pengumpulan data yang dilakukan 
dengan cara member seprangkat pertanyaan atau pernyataan tertulis kepada responden untuk dijawab dengan tujuan mencari informasi yang lengkap mengenai suatu masalah yang diteliti dari responden tanpa merasa khawatir bila responden memberikan jawaban yang tidak sesuai dengan kenyataan dalam pengisian daftar pertanyaan. Observasi merupakan teknik pengumpulan data dengan cara pengamatan secara langsung terhadap aktivitas obyek penelitian untuk melihat dari dekat kegiatan yang dilakukan

Variabel bebas adalah variabel yang bertindak sebagai penyebab atau variabel yang mempengaruhi variabel lain. Di dalam penelitian ini yang termasuk variabel bebas adalah : Pemahaman terhadap keinginan pelanggan (Understanding Customer Expectatio $)\left(\mathrm{X}_{1}\right)$ yaitu upaya perusahaan dalam melakukan indentifikasi apa yang diinginkan oleh konsumen dan memasarkan barang dan jasa diatas tingkat yang konsumen harapkan. Dengan indokator sikap karyawan yang ramah, pelayanan karyawan yang sesuai dengan harapan serta jaminan keamanan simpanan dana nasabah yang sesuai dengan harapan; dan membangun pelayanan kemitraan dengan pelanggan (Building Service Partnership ) $\left(\mathrm{X}_{2}\right)$ yaitu kerajsama yang dilakukan oleh perusahaan dengan konsumen dalam menambahkan pelayanan yang diinginkan oleh konsumen atas suatu produk perusahaan. Dengan indikator kemampuan karyawan untuk mendengarkan dan meninjaklanjuti terhadap keluhan yang disampaikan pelanggan, kemampuan perusahaan dalam melibatkan pelanggan dalam meningkatkan mutu serta kemampuan perusahaan dalam mendorong karyawannya unuk melayani pelanggan dengan ramah dan bersahabat.

Variabel terikat adalah variabel yang tergantung pada variabel lain atau variabel yang dapat dipengaruhi. Variabel terikat dalam penelitian ini adalah loyalitas nasabah (Y) adalah suatu kesetiaan pelanggan terhadap suatu produk atau jasa dimana seorang pelanggan akan melakukan pembelian kembali, konsumen akan melakukan pembelian melalui lini produk, konsumen akan menyebarkan informasi yang positif secara lisan kepada konsumen lain, konsumen memiliki kekebalan dari tarikan perusahaan pesaing. Dengan indikator (Kotler \& Keller, 2006 : 57) pelanggan melakukan pembelian yang berulangulang, pelanggan menunjukkan ketahanan dari daya tarik pesaing serta pelanggan merekomendasikan kepada orang lain.

Dalam menganalisis data yang berhubungan dengan permasalahan yang akan dipecahkan serta penunjang data yang lainnya yang dibutuhkan, maka penulis mempergunakan metode analilis data Deskriptif digunakan untuk menggambarkan atau menganalisis suatu statistic hasil penelitian, tetapi tidak digunakan untuk membuat kesimpulan yang lebih luas (generalisasi/inferensi) (Sugiyono 2012 : 21). Uji instrument data yang terdiri dari Uji Validitas digunakan untuk mengukur sah atau valid tidaknya suatu kuesioner ; Uji Reabilitas adalah alat untuk mengukur suatu kuesioner yang merupakan indicator dari variabel atau konstruk. Alat analisis data yang terdiri dari Analisis Regresi Linier Berganda adalah hubungan secara linier antara dua variabel independen (X) dengan variabel dependen (Y). analisis ini 
untuk mengetahui arah hubungan antara variabel independen dengan variabel dependen apakah masingmasing variabel independen berhubungan positif atau negative dan untuk memprediksi nilai dari variabel dependen apabila nilai dari variabel independen mengalami kenaikan atau penurunan, Uji Koefisien Determinasi untuk mengukur seberapa kauh kemampuan model dalam menerangkan variasi variabel terikat (Ghozali, 2013 : 97), Uji t digunakan untuk mengetahui siginifikansi dari pengaruh variabel independen terhadap variabel dependen secara individual dan menganggap dependen yang lain konstan dan Uji F dipergunakan untuk mengetahui pengaruh bersama-sama variabel bebas (independen) terhadap variabel terkiat (dependen).

\section{HASIL PENELITIAN DAN PEMBAHASAN}

Dari hasil perhitungan analisa regresi linier berganda diperoleh persamaan $\mathrm{Y}=2,403+0,190 \mathrm{X}_{1}+$ $0,277 \quad \mathrm{X}_{2}$ dapat diartikan sebagai berikut : $\mathrm{a}=2,403$ merupakan konstanta yang berarti apabila variabel bebas (Understanding Customer Expectatio dan Building Service Partnership) dalam penelitian pengaruhnya $=0$, maka hasil yang diperoleh dari loyalitas nasabah adalah sebesar 2,403; $b_{1}=0,190$ artinya apabila terjadi kenaikan 1 Understanding Customer Expectatio maka akan menaikkan loyalitas nasabah sebesar 0,190 dengan asumsi variabel lain dianggap nol ( a dan $\mathrm{X}_{2}=$ $0) ; b_{2}=0,277$ artinya apabila terjadi kenaikan 1 Building Service Partnership maka akan menaikkan loyalitas nasabah sebesar 0,277 variabel dengan asumsi variabel lain dianggap nol ( a dan $\mathrm{X}_{1}=0$ ). Sedangkan untuk mencari suatu ukuran yang dapat menyatakan seberapa baik regresi sampel mencocokan data atau ukuran yang lebih berarti dari korelasi (r) adalah dengan koefisien determinasi (R) dimana $\mathrm{R}=0,897$ yang artinya kedua variabel mempunyai hubungan yang sangat kuat yaitu sebesar $89,70 \%$ dan sisanya $10,30 \%$ diperngaruhi oleh variabel lain yang tidak termasuk dalam perhitungan dalam penelitian ini.

Perhitungan secara parsial menggunakan uji $\mathrm{t}$ diperoleh hasil nilai $t_{\text {tabel }}$ dengan tingkat signifikan $\alpha=5 \%$ adalah 2,605. Jadi hasil perhitungan pengaruh Understanding Customer Expectatio $\left(\mathrm{X}_{1}\right)$ terhadap loyalitas nasabah (Y) adalah $\mathrm{t}_{\text {hitung }} 2,605>\mathrm{t}_{\text {tabel }}$ 1,9883 maka Ho ditolak dan $\mathrm{Ha}$ diterima artinya ada pengaruh yang signifikan antara Understanding Customer Expectatio $\left(\mathrm{X}_{1}\right)$ terhadap loyalitas nasabah (Y). Sedangkan hasil perhitungan pengaruh Building Service Partnership $\left(\mathrm{X}_{2}\right)$ terhadap loyalitas nasabah (Y) adalah $\mathrm{t}_{\text {hitung }} 4,283>\mathrm{t}_{\text {tabel }}$ 1,9883 maka Ho ditolak dan $\mathrm{Ha}$ diterima artinya ada pengaruh yang signifikan antara Building Service Partnership $\left(\mathrm{X}_{2}\right)$ terhadap loyalitas nasabah (Y).

Pada uji $\mathrm{F}$ diketahui bahwa $\mathrm{F}_{\text {hitung }}>$ $F_{\text {tabel }}$ sebesar 97, $653>2,465$ dengan taraf signifikan $\alpha=5 \%$, sehingga Ho ditolak dan $\mathrm{Ha}$ diterima. Dapat disimpulkan bahwa secara simultan variabel pemahaman terhadap keinginan pelanggan (Understanding Customer Expectatio $\left(\mathrm{X}_{1}\right)$, Building Service Partnership $\left(\mathrm{X}_{2}\right)$ berpengaruh secara nyata terhadap loyalitas nasabah (Y) di PT. Bank Negara Indonesia (Persero) Tbk Kantor Cabang Pembantu Lamongan. Hal ini menandakan bahwa hipotesis kedua 
yang diajukan dalam penelitian dapat diterima.

Dari seluruh pengujian koefisien regresi diperoleh suatu kesimpulan bahwa variabel membangun pelayanan kemitraan dengan pelanggan (Building Service Partnership) berpengaruh paling dominan terhadap loyalitas nasabah. Hal tersebut ditunjukkan dari besarnya nilai $\mathrm{t}$ sebesar 4,383 dengan tingkat signifikan $0,000<\alpha(0,05)$ dan dengan koefisien korelasi (r) sebesar 0,816 .

\section{KESIMPULAN DAN SARAN \\ Kesimpulan}

Berdasarkan permasalahan yang dijadikan sasaran dari penelitian ini yaitu "Analisis Pengaruh Understanding Customer Expectatio(UCE) Dan Building Service Partnership (BSP) Terhadap Loyalitas Nasabah Pada PT. Bank Negara Indonesia (Persero) Tbk Kantor Cabang Pembantu Lamongan" maka dapat diambil kesimpulan : Hasil Analisis Regresi Linier Berganda diperoleh $\mathrm{Y}=2,403+0,190 \mathrm{X}_{1}+0,277$ $\mathrm{X}_{2}$. Sedangkan untuk mencari suatu ukuran yang dapat menyatakan seberapa baik regresi sampel mencocokan data atau ukuran yang lebih berarti dari korelasi (r) adalah dengan koefisien determinasi (R) dimana $R=0,897$ yang artinya kedua variabel mempunyai hubungan yang sangat kuat yaitu sebesar $89,70 \%$ dan sisanya $10,30 \%$ diperngaruhi oleh variabel lain yang tidak termasuk dalam perhitungan dalam penelitian ini. Pengujian secara parsial diperoleh pada variabel $X_{1}$ pemahaman terhadap keinginan pelanggan (Understanding Customer Expectatio) sebesar $\mathrm{t}_{\text {hitung }}>$ $\mathrm{t}_{\text {tabel }}$ atau 2,605 > 1,98836. Variabel $\mathrm{X}_{2}$ membangun pelayanan kemitraan dengan pelanggan (Building Service Partnership) sebesar $\mathrm{t}_{\text {hitung }}>\mathrm{t}_{\text {tabel }}$ atau $4,283>1,98836$ maka dari hasil tersebut keputusan yang dapat diambil yaitu menolak $\mathrm{H}_{0}$ dan menerima $\mathrm{H}_{1}$, dengan demikian dapat ditarik kesimpulan variabel pemahaman terhadap keinginan pelanggan (Understanding Customer Expectatio) $\left(\mathrm{X}_{1}\right)$, membangun pelayanan kemitraan (Building Service Partnership) $\left(\mathrm{X}_{2}\right)$ secara individual mempunyai pengaruh yang signifikan terhadap variabel loyalitas nasabah (Y). Hasil pengujian secara simultan diperoleh $\mathrm{F}_{\text {hitung }}>\mathrm{F}_{\text {tabel }}$ atau 97, $653>2,465$ maka dapat disimpulkan bahwa ada pengaruh secara simultan antara variabel Understanding Customer Expectatio, Building Service Partnership yaitu Ho ditolak dan Ha diterima yang berarti bahwa hipotesis diterima. Dari seluruh pengujian koefisien regresi diperoleh suatu kesimpulan bahwa variabel membangun pelayanan kemitraan dengan pelanggan (Building Service Partnership ) berpengaruh paling dominan terhadap loyalitas nasabah dengan ditunjukkan dari besarnya nilai $\mathrm{t}$ sebesar 4,283 dengan tingkat signifikan $0,000<\alpha(0,05)$.

\section{Saran}

Berdasarkan hasil dan kesimpulan yang diperoleh, maka diajukan beberapa saran sebagai berikut : Perlunya mempertahankan dan memhami harapan-harapan nasabah dengan cara memberikan penilaian atas kinerja yang telah dilakukan oleh para karyawan front-line, hal tersebut bertujuan untuk mengukur seberapa baik kinerja karyawan front-line dalam upaya peningkatan mutu pelayanan terhadap nasabah. Meningkatkan interaksi langsung denngan nasabah, misalnya 
berupa share and care, saran atau kritik serta penyelesaian atas keluhan yang disampikan oleh nasabah. Memberikan motivasi kepada karyawan agar lebih aktif adalam memberikan pelayanan kepada nasabah.

\section{DAFTAR PUSTAKA}

Alma, Dr. H Buchari. 2011. Manajemen Pemasaran dan Pemasaran Jasa. Cetakan Ke9. Bandung : Alfabeta

Arikunto, Suharsimi. 2010. Prosedur Penelitian Suatu Pendekatan Praktik. Edisi Revisi 2010. Jakarta : PT. Rineka Cipta

Barnes, James G. 2003. Secretes Of

Customer

Management

Manajemen

Pelanggan).

Yogyakarta : ANDI

Chan, Syafruddin. 2003. Realitionship Marketing : Inovasi Pemasaran yang Membuat Pelanggan Bertekuk Lutut. Cetakan Kedua. Jakarta : PT. Gramedia Pustaka Utama

Fandy, Tjiptono. 2008. Strategi $\begin{aligned} & \text { Pemasaran. } \\ & \text { Yogyakarta }\end{aligned}$
OFFSET

Griffin, Jill. 2005. Customer Loyalty : Menumbuhkan \& Mempertahankan Kesetiaan Pelanggan. Jakarta : Erlangga

Hurriyati, Ratih. 2005. Bauran

Pemasaran dan Loyalitas

Konsumen. Bandung : CV.

Alfabeta

Kotler, P. \& Keller, K.,. 2009. Manajemen Pemasaran. Edisi 13. Jilid 1. Jakarta : Erlangga Lupiyoadi, Rambat. 2006. Manajemen Pemasaran Jasa. Cetakan pertama. Edisi Kedua. Jakarta : Salemba Empat

Lupiyoadi, Rambat. 2013. Manajemen

Pemasaran Jasa : Berbasis

Kompetensi. Edisi Tiga. Jakarta : Salemba Empat

Riduwan. 2012. Skala Pengukuran

Variabel-Variabel Penelitian.

Cetakan Kesepuluh. Bandung :

Alfabeta

Sugiyono. 2013. Metode Penelitian

Pendidikan Pendekatan

Kuantitatif Kualitatif Dan

R\&D. Cetakan Ke-16. Bandung : Alfabeta

Sugiyono. 2013. Statistika Untuk

Penelitian. Cetakan Ke-22.

Bandung : Alfabeta

Sayuti, Maulana. 2011. Pengaruh Implementasi Relationship Marketing Terhadap Customer Loyalty pada PT. Bank Negara Indonesia (Persero), tbk. Kantor Cabang Utama Mattoangin Makassar. Skripsi Online. Fakultas Ekonomi. Universitas Hasanuddin Makassar

Wibowo, Lilik Afi. 2007. Pengaruh Implementasi Relationship Marketing Terhadap Customer Loyalty (Studi Kasus Pada PT. Bank Rakyat Indonesia Cabang Cik Di Tiro di Yogyakarta. Skripsi Online. Fakultas Ekonomi. Universitas Muhammadiyah Yogyakarta

(http://www.bni.co.id) . Diakses pada tanggal 04 Januari 2014. Pukul 21.47 WIB 